Jurnal Agro 8(1), 2021

\title{
PENGARUH MEDIA TUMBUH DENGAN APLIKASI IRIGASI TETES TERHADAP PERTUMBUHAN DAN HASIL MELON
}

\section{THE EFFECT OF GROWING MEDIA WITH DRIP IRRIGATION APPLICATION ON MELON GROWTH AND YIELD}

\author{
Didi Carsidi ${ }^{1}$, Saparso ${ }^{1}$, Kharisun ${ }^{1}$, Catur Rahardjo Febrayanto ${ }^{2}$ \\ ${ }^{1}$ Program Studi Pascasarjana Agronomi, Fakultas Pertanian, Unsoed, Purwokerto \\ JI. DR. Soeparno, Karang Bawang, Karangwangkal, Kec. Purwokerto Utara, Kabupaten \\ Banyumas, Jawa Tengah 53122 \\ ${ }^{2} \mathrm{PT}$. East West Seed Indonesia, Purwakarta \\ Benteng, Kec. Campaka, Kabupaten Purwakarta, Jawa Barat 41181
}

Korespondensi : akh.carsidi@gmail.com

Diterima : 10 September 2020 / Disetujui : 06 Juli 2021

\begin{abstract}
ABSTRAK
Penggunaan media tumbuh dan volume air yang tepat menentukan pertumbuhan dan hasil tanaman melon. Penelitian ini bertujuan untuk mengetahui volume air optimum pada media tumbuh tertentu yang dapat menghasilkan pertumbuhan dan hasil yang optimum. Penelitian menggunakan rancangan split plot $4 \times 3$, dengan tiga ulangan. Petak utama yaitu volume irigasi tetes dengan empat taraf; $600 \mathrm{ml} \mathrm{hari}^{-1} \tan ^{-1}, 1200 \mathrm{ml} \mathrm{hari}^{-1} \tan ^{-1}, 1800 \mathrm{ml} \mathrm{hari}^{-1} \tan ^{-1}$ dan 2400 $\mathrm{ml}$ hari $^{-1} \tan ^{-1}$ sedangakan anakan petak yaitu media tumbuh dengan tiga taraf; tanah + arang sekam, tanah + cocopeat, serta tanah + bokhasi. Parameter yang diamati yaitu tinggi tanaman, jumlah daun, total panjang akar tanaman, luas daun, kandungan air nisbi daun, prolin, lebar bukaan stomata, kerapatan stomata, kadar klorofil, umur berbunga, bobot tanaman basah, bobot tanaman kering, bobot buah, lingkaran buah, brix buah, kadar air buah melon, dan kandungan NPK jaringan daun melon. Hasil penelitian menunjukkan volume air $600 \mathrm{ml} \mathrm{hari}^{-1} \tan ^{-}$ ${ }^{1}$ optimum dengan media tumbuh tanah + bokhasi pada bobot tanaman segar (1083.33 g) sedangkan volume air $1200 \mathrm{ml} \mathrm{hari}^{-1} \tan ^{-1}$ dengan media tumbuh tanah + bokhasi memberikan pengaruh terhadap bobot tanaman kering $(95.80 \mathrm{~g})$. Jenis media tumbuh memiliki kapasitas volume air yang berbeda untuk pertumbuhan dan hasil tanaman yang optimal.
\end{abstract}

Kata kunci : Hasil, Irigasi, Media tumbuh, Melon, Pertumbuhan

\begin{abstract}
The proper growing media and water volume provide the growth and yield of melon plants. This study aimed to determine the optimum water volume in certain growth media to optimize the growth and yield. The study used a $4 \times 3$ split plot design with three replications. The main plots were volume of drip irrigations i.e $600 \mathrm{ml} \mathrm{day}^{-1} \tan ^{-1}, 1200 \mathrm{ml} \mathrm{day}^{-1} \tan ^{-1}, 1800 \mathrm{ml} \mathrm{day}^{-1} \tan ^{-}$ ${ }^{1}$, and $2400 \mathrm{ml} \mathrm{day}^{-1} \tan ^{-1}$ while the sub plots were growing media with three levels i.e soil + husk charcoal, soil + cocopeat, and soil + bokashi. The observed parameters were plant height, leaf
\end{abstract}

ISSN : 2407-7933

68

Cite this as: Carsidi D., Saparso., Kharisun. \& Febrayanto C R. (2021). Pengaruh media tumbuh dengan aplikasi irigasi tetes terhadap pertumbuhan dan hasil melon. Jurnal Agro, 8(1), 68-83. 
number, total plant root length, leaf area, leaf relative water content, proline, stomatal opening width, stomata density, chlorophyll content, flowering age, wet plant weight, dry plant weight, fruit weight, fruit circle, fruit brix, the fruit water content, and NPK content in leaf tissue. The water volume of $600 \mathrm{ml} \mathrm{day}^{-1} \tan ^{-1}$ is optimum with growing media soil + bokashi on fresh plant weight (1083.33 g) while the water volume of $1200 \mathrm{ml} \mathrm{day}^{-1} \tan ^{-1}$ with soil + bokhasi growing media had an effect on dry plant weight $(95.80 \mathrm{~g})$. The types of growing media have different water volume capacities for optimal plant growth and yields.

Keywords : Growing media, Growth, Irrigation, Melon, Yield

\section{PENDAHULUAN}

Buah Melon (Cucumis melo L.) di Indonesia merupakan salah satu komoditas unggulan. Masyarakat Indonesia sangat menyukai buah melon karena rasanya manis dan enak serta kandungan gizinya sangat tinggi (Diding et al., 2015). Daging buah melon mengandung air, protein, lemak, karbohidrat, serat, abu dan vitamin A 357 IU masing-masing $92,1,1,5,0,3,6,2,0,5$, dan $0,4 \%$. Buah melon ini menjadi salah satu buah sumber energi karena dalam $100 \mathrm{~g}$ berat yang dapat dimakan mengandung kalori (21 kalori), karbohidrat $(5,1 \mathrm{~g})$, protein $(0,6 \mathrm{~g})$, lemak $(0,1 \mathrm{~g})$ dan beberapa vitamin serta mineral lain yang sangat dibutuhkan untuk tumbuh (Budi \& Sigit, 2017).

Air adalah sumber kehidupan dan sangat menentukan pertumbuhan tanaman. Ketersediaan air dan respon tanaman terhadap air juga ikut mempengaruhi proses pertumbuhan dan hasil tanaman (Mawardi, 2016). Faktor produksi (media tumbuh, air, nutrisi dan lain-lain), adalah faktor pembatas yang paling sering pada produksi hasil melon (Monteiro et al., 2014). Volume irigasi mempengaruhi pertumbuhan tanaman melon seperti yang dilaporkan oleh Manh \& Wang (2014) bahwa peningkatan ketersediaan air dapat meningkatkan tinggi tanaman, luas daun dan bobot biomasa tanaman melon.

Ketersedian air yang dipakai untuk keperluan irigasi tanaman di PT. East West
Seed Indonesia sangat melimpah karena menggunakan sumur bor. Sumber air dengan kedalaman sumur $100 \mathrm{~m}$, titik pompa ada di 45 sampai $50 \mathrm{~m}$. Permasalahannya adalah biaya air yang dikeluarkan sangat besar sehingga perlu penggunaan air yang tepat dan efisien. Irigasi tetes adalah metode pemberian air dengan volume air yang disesuikan dengan penggunaan air tanaman, sehingga meminimalkan kehilangan air karena perkolasi, aliran permukaan dan evaporasi. Sistem ini memberikan air dengan lambat untuk mempertahankan kelembaban media tumbuh pada selang yang diharapkan untuk pertumbuhan tanaman (Rosadi, 2015).

Media tumbuh yang digunakan sebagai media tumbuh tanaman banyak jenisnya. Menurut Irawan (2015) bahan-bahan organik terutama yang bersifat limbah yang ketersediaannya melimpah dan murah dapat dimanfaatkan untuk alternatif media tumbuh yang sulit tergantikan serta bahan organik mempunyai sifat remah sehingga udara, air, akar mudah masuk dalam fraksi tanah dan dapat mengikat air, $\mathrm{Hal}$ ini sangat penting bagi akar tanaman karena media tumbuh sangat berkaitan dengan pertumbuhan akar atau sifat di perakaran tanaman. Media organik dengan komposisi bokashi, cocopeat, arang sekam dapat meningkatkan kandungan gula total pada buah melon (Bariyyah et al., 2015). Tujuan penelitian adalah untuk mengetahui : (1) 
Pengaruh volume air dengan irigasi tetes terhadap pertumbuhan dan hasil. (2) Pengaruh media tumbuh terhadap pertumbuhan dan hasil. (3) Pengaruh volume air dengan irigasi tetes pada media tumbuh berbeda terhadap pertumbuhan dan hasil. (4) Volume air optimum pada media tumbuh tertentu yang mampu mengasilkan pertumbuhan dan hasil optimum.

\section{BAHAN DAN METODE}

\section{Tempat dan Waktu}

Penelitian dilaksanakan di Greenhouse PT. East West Seed Indonesia, Purwakarta, Provinsi Jawa Barat pada bulan September hingga Desember 2019.

\section{Alat dan Bahan}

Bahan yang digunakan; benih melon Gracia F1, tanah, sekam bakar, cocopeat, bokhasi, Pupuk NPK Mutiara. Alat yang digunakan; perangkat irigasi tetes, greenhouse (screen), polibag ukuran $20 \times 40$ (berlubang), dan yang lainnya.

\section{Rancangan Percobaan}

Penelitian dilaksanakan menggunakan rancangan Split Plot $4 \times 3$ diulang sebanyak 3 kali. Petak utama yaitu volume air irigasi tetes pemberian tiga kali sehari (pagi,siang dan sore) dengan 4 taraf: $\mathrm{V} 1=600 \mathrm{ml} \mathrm{hari}^{-1}$ $\tan ^{-1}$ (200 ml per satu kali pemberian), V2 = $1200 \mathrm{ml} \mathrm{hari}^{-1} \tan ^{-1}$ (400 ml per satu kali pemberian), $\mathrm{V} 3=1800 \mathrm{ml} \mathrm{hari}^{-1} \tan ^{-1}(600 \mathrm{ml}$ per satu kali pemberian), $\mathrm{V} 4=2400 \mathrm{ml}^{2}$ hari ${ }^{1} \tan ^{-2}$ (800 ml per satu kali pemberian). Anak petak yaitu media tumbuh dengan 3 taraf jenis media tumbuh; $\mathrm{M} 1=$ Tanah dan arang sekam, M2 = Tanah dan cocopeat, M3 = Tanah dan Bokashi (kotoran Sapi), dengan masing-masing berat media tumbuh $8,10 \mathrm{Kg}$; $10,46 \mathrm{Kg}$ dan $8,48 \mathrm{Kg}$.

Variabel diamati yaitu tinggi tanaman $(\mathrm{cm})$, jumlah daun (helai), total panjang akar tanaman $(\mathrm{cm})$, bobot tanaman basah $(\mathrm{g})$, bobot tanaman kering $(\mathrm{g})$, Luas daun $\left(\mathrm{cm}^{2}\right)$; Perhitungan luas daun didasarkan atas persamaan berikut (Susilo, 2015):

LD $: p \times l \times k$

Dimana: P : Panjang ; I : Lebar; k : Konstanta daun melon $=0,9$. pengamatan dialakukan 14 HST, 28 HST dan 42 HST.

Kandungan air nisbi daun (KAND); kandungan air nisbi daun ditentukan terhadap daun atas, tengah dan bawah tanaman. Daun sampel ditentukan berat segarnya (Fresh Weight, FW). KAN ditentukan dengan merendam sample daun 12 jam di tempat gelap. Berat turgot (Turgid Weight, TW) ditentukan setelah dikeringkat dengan dikibaskan 3 kali. Berat kering (Dry weight, DW) ditentukan dengan cara mengeringkan sample daun selama 24 jam pada suhu $80{ }^{\circ} \mathrm{C}$. Perhitungan KAND dengan rumus (Setiawan et al., 2013):

$$
\text { KAND }=\frac{F W-D W}{T W-D W} \times 100 \%
$$

Kadar prolin daun; pengamatan dilakukan saat tanaman fase generatif, Kadar prolin ditentukan terhadap daun tengah dari letak daun yang dianggap sudah berkembang sempurna dengan metode Bates et al. (1973); (Ashari et al., 2018). Kadar prolin ditentukan mempergunakan persamaan:

Kadar prolin $=$ Bacaan absorbansi $\left(\mathrm{mg} \mathrm{cm}^{-3}\right) \mathrm{x}$

$$
0,347 \mu \mathrm{mol} \mathrm{g}^{-1}
$$


Lebar bukaan stomata $(\mu \mathrm{m})$, Kerapatan Stomata $\left(\mathrm{mm}^{2}\right)$ dan kadar klorofil $\left(\mu \mathrm{g} \mathrm{ml}^{-1}\right)$; pengamatan dilakukan saat tanaman fase generatif, terhadap daun tengah dari letak daun yang dianggap sudah berkembang sempurna. Perhitungan kadar klorofil diperoleh menggunakan rumus (Pratama \& Laily, 2015):
Klorofil $a=(13,7 \times A 665)-(5,76 \times A 649)$

Klorofil $b=(25,8 \times A 649)-(7,60 \times A 665)$

Kandungan Klorofil Total $=$ Klorofil $a+$ Klorofil $b$

Tabel 1. Sifat kimia media tumbuh

\begin{tabular}{cccccc}
\hline \multirow{2}{*}{ No } & \multirow{2}{*}{ Parameter Analisis } & \multirow{2}{*}{ Satuan } & \multicolumn{3}{c}{ Hasil Analisis Media Tumbuh } \\
\cline { 4 - 6 } & & $\mathrm{M} 1$ & $\mathrm{M} 2$ & $\mathrm{M} 3$ \\
\hline 1 & $\mathrm{pH}\left(\mathrm{H}_{2} \mathrm{O}\right)$ & & 6,8 & 6,3 & 7 \\
\hline 2 & $\mathrm{KTK}$ & $\mathrm{cmol} / \mathrm{kg}$ & 16,6 & 23,79 & 23,24 \\
\hline 3 & $\mathrm{P}_{2} \mathrm{O}_{5}(\mathrm{Olsen})$ & $\mathrm{ppm}$ & 52 & 60 & 396 \\
\hline 4 & $\mathrm{P}_{2} \mathrm{O}_{5}(\mathrm{HCl} 25 \%)$ & $\mathrm{ppm}$ & 904 & 864 & 3420 \\
\hline 5 & $\mathrm{~K} 2 \mathrm{O}(\mathrm{HCl} \mathrm{25 \% )}$ & $\mathrm{ppm}$ & 1098 & 1635 & 5613 \\
\hline 6 & $\mathrm{~N}-$-Total & $\%$ & 0,17 & 0,08 & 0,53 \\
\hline 7 & $\mathrm{C}-$ Organik & $\%$ & 4,3 & 5,3 & 7,2 \\
\hline 8 & $\mathrm{C} / \mathrm{N}$ & & 25,3 & 66,3 & 13,6 \\
\hline 9 & $\mathrm{~N}-\mathrm{NH}_{4}$ & $\mathrm{ppm}$ & 48,9 & 39,8 & 61,2 \\
\hline 10 & $\mathrm{~N}-\mathrm{NO}_{3}$ & $\mathrm{ppm}$ & 268,4 & 265,6 & 417,9 \\
\hline
\end{tabular}

Sumber: Analisis di laboratorium PT. Pupuk Kujang dan balitsa Lembang.

Keterangan:

M1 = Tanah dan arang sekam; M2 = Tanah dan cocopeat; M3 = Tanah dan bokhasi.

Sangat masam

Masam

agak masam

Netral

Agak Alkalis

Alkalis

\begin{tabular}{|l|}
\hline Sangat Rendah \\
Rendah \\
Sedang \\
Tinggi \\
\hline Sangat Tinggi
\end{tabular}

Sangat Tinggi
Umur berbunga (hst); umur berbunga dicatat ketika tanaman keluar bunga pertama. Variabel buah melon; bobot buah melon (g), lingkaran buah melon (cm), Brix buah melon dan kadar air buah melon (\%); pengukuran kadar air buah melon menggunakan metode gravimetrik. Kadar air diperoleh dengan menggunakan rumus (Muttaqin \& Amalia, 2019):

Kadar air $(\%)=\frac{\text { Bobot Awal }- \text { Bobot Akhir }}{\text { Bobot Awal }} \times 100 \%$
Variabel Pendukung yang diamati; sifat kimia media tumbuh (Tabel 1) dan analisis kimia NPK jaringan daun pada fase generatif.

\section{Analisis Data}

Analisis data hasil pengamatan dilakukan dengan Sidik Ragam dengan taraf nyata 5\% dan apabila hasil analisis berpengaruh, maka dilanjutkan dengan uji lanjut Duncan Multiple Range Test (DMRT) pada taraf 5\%. 


\section{HASIL DAN PEMBAHASAN}

Data pada Tabel 2. Menunjukan nilai probabilitas (P-Value) dan koefisien keragaman (KK) dari hasil Analisis varians pada setiap parameter pertumbuhan dan hasil tanaman melon.

Tabel 2. Hasil analisis varians pada setiap parameter pertumbuhan dan hasil tanaman melon

\begin{tabular}{lllll}
\hline \multirow{2}{*}{ Parameter } & \multicolumn{3}{c}{ Nilai Probabilitas (P-Value) } & \multirow{2}{*}{ KK (\%) } \\
\cline { 2 - 3 } & \multicolumn{1}{c}{$\mathrm{V}$} & $\mathrm{M}$ & $\mathrm{V} \times \mathrm{M}$ & \\
\hline Tinggi tanaman 42 HST & $0,46^{\text {tn }}$ & $0,26^{\text {tn }}$ & $0,30^{\text {tn }}$ & 17,57 \\
Jumlah daun 42 HST & $0,72^{\text {tn }}$ & $0,03^{*}$ & $0,49^{\text {tn }}$ & 16,65 \\
Luas daun 42 HST & $0,50^{\text {tn }}$ & $0,00^{* *}$ & $0,20^{\text {tn }}$ & 19,40 \\
Total panjang akar 42 HST & $0,06^{\text {tn }}$ & $0,00^{* *}$ & $0,31^{\text {tn }}$ & 19,68 \\
Bobot tanaman segar 42 HST & $0,86^{\text {tn }}$ & $0,00^{* *}$ & $0,047^{*}$ & 21,32 \\
Bobot tanaman kering 42 HST & $0,52^{\text {tn }}$ & $0,00^{* *}$ & $0,02^{*}$ & 21,83 \\
Umur berbunga & $0,73^{\text {tn }}$ & $0,00^{* *}$ & $0,07^{\text {tn }}$ & 2,58 \\
Bukaan stomata & $0,32^{\text {tn }}$ & $0,92^{\text {tn }}$ & $1,00^{\text {tn }}$ & 36,33 \\
Kerapatan stomata & $0,14^{\text {tn }}$ & $0,70^{\text {tn }}$ & $0,42^{\text {tn }}$ & 16,66 \\
Klorofil a & $0,01^{* *}$ & $0,19^{\text {tn }}$ & $0,07^{\text {tn }}$ & 8,72 \\
Klorofil b & $0,29^{\text {tn }}$ & $0,26^{\text {tn }}$ & $0,36^{\text {tn }}$ & 36,80 \\
Klorofil total & $0,09^{\text {tn }}$ & $0,16^{\text {tn }}$ & $0,12^{\text {tn }}$ & 16,67 \\
Kandungan N jaringan daun & $0,00^{* *}$ & $0,22^{\text {tn }}$ & $0,18^{\text {tn }}$ & 14,80 \\
Kandungan P jaringan daun & $0,38^{\text {tn }}$ & $0,00^{* *}$ & $0,08^{\text {tn }}$ & 17,70 \\
Kandungan K jaringan daun & $0,06^{\text {tn }}$ & $0,02^{*}$ & $0,39^{\text {tn }}$ & 14,08 \\
Bobot buah & $0,09^{\text {tn }}$ & $0,00^{* *}$ & $0,09^{\text {tn }}$ & 14,54 \\
Brix buah & $0,46^{\text {tn }}$ & 0,09 tn & $0,10^{\text {tn }}$ & 9,89 \\
Lingkar buah & $0,10^{\text {tn }}$ & $0,00^{* *}$ & $0,06^{\text {tn }}$ & 5,01 \\
Kadar air buah & $0,81^{\text {tn }}$ & $0,16^{\text {tn }}$ & $0,08^{\text {tn }}$ & 0,49 \\
Prolin & $0,54^{\text {tn }}$ & $0,32^{\text {tn }}$ & $0,10^{\text {tn }}$ & 37,26 \\
KAND & $0,046^{*}$ & $0,15^{\text {tn }}$ & $0,32^{\text {tn }}$ & 3,02 \\
\hline
\end{tabular}

Keterangan: $\mathrm{V}=$ Faktor volume air; $\mathrm{M}=$ Faktor media tumbuh ; $\mathrm{VX} \mathrm{M}=$ Interaksi antara faktor $\mathrm{V}$ dan faktor $M ;{ }^{*}=$ berpengaruh nyata $(p<0,05) ;{ }^{* *}=$ berpengaruh sangat nyata $(p<0,05)$; tn = tidak berbeda nyata $(p>0,05) ; K K=$ Koefisien keragagaman

\section{Tinggi Tanaman dan Jumlah Daun}

Data pada Tabel 3. Menunjukkan bahwa volume pemberian air maupun media tumbuh tidak berpengaruh nyata pada tinggi tanaman dan jumlah daun melon saat umur 42 HST. Hasil analisis tinggi tanaman dan jumlah daun melon pada M3 (tanah dan bokhasi) saat destruksi pada umur 14 HST dan 28 HST menunjukkan bahwa dapat meningkatkan tinggi tanaman dan jumlah daun daripada media tumbuh M1 (tanah dan arang sekam) dan M2 (tanah dan cocopeat) dengan nilai masing-masing $20,92 \mathrm{~cm}, 12,08$ helai dan 175,92 cm, 30,83 helai. Hal ini diduga pencampuran media tumbuh tanah dengan bokashi mempunyai peranan yang baik dalam meningkatkan laju pertumbuhan tanaman. Apabila unsur hara meningkat terutama nitrogon meningkat maka klorofil juga meningkat sehingga fotosintat yang 
dihasilkan juga meningkat dan diakumulasikan ke pertumbuhan panjang tanaman dan jumlah daun (Muhadan et al., 2016). Hasil pengamatan dan analisis data tinggi tanaman dan jumlah daun pada destruksi umur 42 HST menunjukkan hasil yang berbeda (media tumbuh tidak berpengaruh nyata terhadap tinggi tanaman dan jumlah daun). Hal tersebut diduga disebabkan destruksi pada hari 42 HST sudah dilakukan pemangkasan atau topping batang apikal atas pada sebagian tanaman melon di luar perlakuan penelitian sehingga tidak mengalami perpanjangan tanaman lagi ke atas, karena Menurut Laksono (2018) pemangkasan toping (pucuk) mampu menghentikan laju dominasi apikal sehingga dapat memacu pertumbuhan cabang. Menurut Rasilatu et al. (2016) pemangkasan pucuk dapat menekan pertumbuhan tanaman sehingga asimilat dapat terkonsentrasi pada pembentukan buah.

Tabel 3. Rataan tinggi tanaman dan jumlah daun pada umur 14 HST, 28 HST dan 42 HST pada perlakuan volume air dan media tumbuh

\begin{tabular}{|c|c|c|c|c|c|c|}
\hline \multirow{3}{*}{ Perlakuan } & \multicolumn{3}{|c|}{ Tinggi Tanaman $(\mathrm{cm})$} & \multicolumn{3}{|c|}{ Jumlah Daun ( Helai) } \\
\hline & \multicolumn{6}{|c|}{ Umur Tanaman } \\
\hline & $14 \mathrm{HST}$ & 28 HST & $42 \mathrm{HST}$ & $14 \mathrm{HST}$ & $28 \mathrm{HST}$ & $42 \mathrm{HST}$ \\
\hline V1 & $13,89 a$ & $105,22 \mathrm{a}$ & 203,44 a & $7,33 \mathrm{a}$ & $20,11 \mathrm{a}$ & $26,67 \mathrm{a}$ \\
\hline V2 & $15,17 \mathrm{a}$ & $111,44 a$ & 194,11 a & 6,78 a & $18,78 \mathrm{a}$ & $25,56 \mathrm{a}$ \\
\hline V3 & $16,22 a$ & $114,56 \mathrm{a}$ & 208,56 a & $7,00 \mathrm{a}$ & $22,22 \mathrm{a}$ & $24,56 \mathrm{a}$ \\
\hline V4 & $13,39 a$ & $115,33 \mathrm{a}$ & $185 \mathrm{a}$ & 5,89 a & $21,78 \mathrm{a}$ & $26,89 \mathrm{a}$ \\
\hline KK (\%) & 15,42 & 14,19 & 17,57 & 26,42 & 14,76 & 16,65 \\
\hline M1 & $9,21 \mathrm{c}$ & $54,08 \mathrm{c}$ & 210,92 a & $3,00 \mathrm{~b}$ & $12,25 c$ & $28,50 \mathrm{a}$ \\
\hline M2 & $13,88 \mathrm{~b}$ & $104,92 \mathrm{~b}$ & 186,83 a & $5,17 \mathrm{~b}$ & $19,08 \mathrm{~b}$ & $25,92 \mathrm{a}$ \\
\hline M3 & $20,92 a$ & $175,92 \mathrm{a}$ & $195,58 \mathrm{a}$ & $12,08 \mathrm{a}$ & $30,83 \mathrm{a}$ & $23,33 \mathrm{a}$ \\
\hline
\end{tabular}

Keterangan: Angka-angka yang diikuti oleh huruf kecil yang sama pada kolom yang sama tidak berpengaruh nyata menurut uji lanjut DMRT pada taraf $\alpha=5 \%$; HST $=$ Hari setelah tanam; KK $=$ Koefisien keragaman.

\section{Luas Daun}

Data pada Tabel 4. Menunjukan perlakuan volume air irigasi tetes tidak berpengaruh nyata terhadap luas daun melon. Diduga kondisi air tercukupi di semua perlakuan volume air sehingga tidak mengganggu proses transportasi atau metabolisme tanaman melon, karena Kebutuhan irigasi tanaman melon selama fase pertumbuhan vegetatif adalah $170 \mathrm{ml}$ per hari per tanaman, sedangkan selama fase generatif adalah $234 \mathrm{ml}$ per hari per tanaman (Sulistyono \& Riyanti, 2016). Perlakuan media tumbuh terhadap luas daun melon berpengaruh sangat nyata. Luas daun melon terluas media tumbuh $\mathrm{M} 3$ (tanah dan bokhasi) senilai rata-rata 347,09 $\mathrm{cm}^{2}$, diduga karena dilihat pada data Tabel 1 dan 8. Kandungan unsur hara fospor media tumbuh dan jaringan daun pada M3 (tanah dan bokhasi) lebih banyak daripada media tumbuh M1 (tanah dan arang sekam) maupun M2 (tanah dan cocopeat). Menurut Dede et al. (2015) Selain disebabkan oleh ketersediaan unsur hara nitrogen media tumbuh, unsur fosfor juga berpengaruh dalam proses pembentukan daun. Proses pembentukan daun tidak terlepas dari peranan unsur hara seperti nitrogen dan fosfor yang tersedia bagi tanaman, Kedua 
unsur hara ini berperan dalam pembentukan sel - sel baru dan komponen utama penyusun senyawa organik dalam tanaman yang mempengaruhi pertumbuhan vegetatif tanaman, khususnya peningkatan luas daun.

Tabel 4. Rataan luas daun, total panjang akar, bobot tanaman segar, bobot tanaman kering, umur berbunga, bukaan stomata dan kerapatan stomata pada perlakuan volume air dan media tumbuh

\begin{tabular}{cccccccc}
\hline Perlakuan & $\begin{array}{c}\text { Luas } \\
\text { Daun } \\
\left(\mathrm{cm}^{2}\right)\end{array}$ & $\begin{array}{c}\text { Total } \\
\text { Panjang } \\
\text { Akar }(\mathrm{cm})\end{array}$ & $\begin{array}{c}\text { Bobot } \\
\text { Tanaman } \\
\text { Segar }(\mathrm{g})\end{array}$ & $\begin{array}{c}\text { Bobot } \\
\text { Tanaman } \\
\text { Kering }(\mathrm{g})\end{array}$ & $\begin{array}{c}\text { Umur } \\
\text { Berbunga } \\
(\mathrm{HST})\end{array}$ & $\begin{array}{c}\text { Bukaan } \\
\text { Stomata } \\
(\mu \mathrm{m})\end{array}$ & $\begin{array}{c}\text { Kerapatan } \\
\text { Stomata } \\
\left(\mathrm{mm}^{2}\right)\end{array}$ \\
\hline V1 & $272,69 \mathrm{a}$ & $1261,11 \mathrm{a}$ & $883,33 \mathrm{a}$ & $62,83 \mathrm{a}$ & $22,98 \mathrm{a}$ & $1,53 \mathrm{a}$ & $268,17 \mathrm{a}$ \\
V2 & $256,64 \mathrm{a}$ & $1502,89 \mathrm{a}$ & $894,44 \mathrm{a}$ & $63,47 \mathrm{a}$ & $23,07 \mathrm{a}$ & $2,08 \mathrm{a}$ & $270,51 \mathrm{a}$ \\
V3 & $294,25 \mathrm{a}$ & $1321,67 \mathrm{a}$ & $844,44 \mathrm{a}$ & $67,06 \mathrm{a}$ & $22,89 \mathrm{a}$ & $2,08 \mathrm{a}$ & $257,85 \mathrm{a}$ \\
V4 & $244,90 \mathrm{a}$ & $1403,39 \mathrm{a}$ & $766,67 \mathrm{a}$ & $53,83 \mathrm{a}$ & $23,13 \mathrm{a}$ & $2,08 \mathrm{a}$ & $267,70 \mathrm{a}$ \\
\hline KK (\%) & 19,40 & 19,68 & 21,32 & 21,83 & 2,58 & 36,33 & 16,66 \\
\hline M1 & $198,65 \mathrm{~b}$ & $1148,75 \mathrm{~b}$ & $504,17 \mathrm{~b}$ & $45,78 \mathrm{~b}$ & $26,98 \mathrm{a}$ & $1,88 \mathrm{a}$ & $274,97 \mathrm{a}$ \\
M2 & $255,62 \mathrm{~b}$ & $1114,21 \mathrm{~b}$ & $791,67 \mathrm{~b}$ & $54,17 \mathrm{~b}$ & $22,78 \mathrm{~b}$ & $1,98 \mathrm{a}$ & $262,31 \mathrm{a}$ \\
M3 & $347,09 \mathrm{a}$ & $1853,83 \mathrm{a}$ & $1245,83 \mathrm{a}$ & $85,44 \mathrm{a}$ & $19,28 \mathrm{c}$ & $1,98 \mathrm{a}$ & $260,90 \mathrm{a}$ \\
\hline
\end{tabular}

Keterangan: Angka-angka yang diikuti oleh huruf kecil yang sama pada kolom yang sama tidak berpengaruh nyata menurut uji lanjut DMRT pada taraf $\alpha=5 \%$; HST = Hari setelah tanam; KK $=$ Koefisien keragaman.

\section{Total Panjang Akar}

Data pada Tabel 4. Menunjukan perlakuan volume air irigasi tetes tidak berpengaruh nyata terhadap total panjang akar melon. Hal ini mengindikasikan bahwa kondisi air setiap volume cukup, karena menurut Rosawanti (2016) jika tanaman kekurangan air atau tercekam air mengalami perubahan respon terhadap kekurangan air dengan memperbanyak cabang akar, perubahan fisiologi tersebut dikarenakan akar memperluas volume untuk memperluas daerah penyerapan air. Perlakuan media tumbuh berpengaruh sangat nyata terhadap total panjang akar melon. Total panjang akar melon terpanjang media tumbuh M3 (tanah dan bokhasi) yaitu 1853,83 cm. Dilihat pada data Tabel 1. dan 8. Kandungan unsur hara fosfor media tumbuh dan jaringan daun M3 (tanah dan bokhasi) lebih tinggi daripada media tumbuh M1 (tanah dan arang sekam) maupun M2 (tanah dan cocopeat). Menurut
(Wahyuningsih et al., 2017) fosfor yang diserap oleh tanaman mampu merangsang pembentukan atau pertumbuhan akar, sehingga pertumbuhan tanaman menjadi lebih baik.

\section{Bobot Tanaman Segar dan Bobot Tanaman Kering \\ Data pada Tabel 4. Menunjukan} perlakuan volume air irigasi tetes tidak berpengaruh nyata terhadap bobot tanaman segar maupun bobot tanaman kering melon. Hal ini diduga kondisi air cukup disetiap perlakuan volume air untuk transportasi dan metabolisme tanaman. Perlakuan media tumbuh berpengaruh sangat nyata terhadap bobot tanaman segar maupun bobot tanaman kering melon. Bobot tanaman segar melon terberat media tumbuh M3 (tanah dan bokhasi) yaitu 1245,83 g. Bobot tanaman kering melon terberat media tumbuh M3 (tanah dan bokhasi) dengan nilai 
rata-rata 85,44 g, Dilihat pada data Tabel 1. Selain kandungan unsur NPK media tumbuh yang sangat tinggi, kandungan rasio $\mathrm{C} / \mathrm{N}$ media tumbuh M3 (tanah dan bokhasi) lebih rendah daripada media tumbuh M1 (tanah dan arang sekam) dan M2 (tanah dan cocopeat), sehingga rasio $\mathrm{C} / \mathrm{N}$ yang lebih rendah berarti media tumbuh $\mathrm{M} 3$ (tanah dan bokhasi) mengandung banyak nitrogen dan mudah terdekomposisi serta akan cepat memasok nitrogen bagi tanaman. Apabila unsur hara dalam jumlah cukup dan aktivitas enzim berlangsung lancar akan meningkatkan laju fotosintesis sehingga dapat meningkatkan laju asimilasi tanaman, laju asimilasi meningkat diikuti dengan jumlah daun, peningkatan bobot buah dan bobot tanaman (Kurniastuti \& Faustina, 2019). Menurut Darmawan et al. (2013) berat tanaman mencerminkan bertambahnya protoplasma, hal ini terjadi akibat ukuran dan jumlah selnya bertambah. Pertumbuhan protoplasma berlangsung melalui peristiwa metabolisme dimana air, karbon dioksida dan garam-garam anorganik diubah menjadi cadangan makanan dengan adanya proses fotosintesis, Meningkatnya luas daun berarti kemampuan daun untuk menerima dan menyerap cahaya matahari akan lebih tinggi sehingga fotosintat dan akumulasi bahan kering akan lebih tinggi pula.

Bobot tanaman segar melon berkolerasi positif terhadap luas daun $(0,824)$, lingkar buah $(0,719)$, bobot tanaman kering $(0,863)$, bobot buah $(0,731)$, serta berkolerasi negatif terhadap umur berbunga melon $(-0,798)$, sehingga semakin luas daun, besarnya lingkar buah dan semakin berat bobot tanaman kering, bobot buah serta lebih cepat umur berbunga melon maka akan diikuti kenaikan berat bobot tanaman segar melon. Bobot tanaman kering melon berkolerasi positif terhadap luas daun $(0,831)$ dan bobot tanaman segar melon $(0,863)$, semakin luas daun melon dan semakin berat bobot tanaman segar melon maka akan diikuti kenaikan berat bobot tanaman kering melon.

Perlakuan volume air dan media tumbuh berinteraksi pada bobot tanaman segar melon. Data pada Tabel 5. Menunjukan perlakuan volume air dan media tumbuh optimum pada bobot tanaman segar melon adalah V1M3 (600 $\mathrm{ml} \mathrm{hari}^{-1} \tan ^{-1}$ dengan media tumbuh tanah dan bokhasi) dengan nilai $1083,33 \mathrm{~g}$. Perlakuan volume air dan media tumbuh berinteraksi pada bobot tanaman kering melon.

Tabel 5. Rataan bobot tanaman segar melon pada perlakuan interaksi antara volume air dan media tumbuh

\begin{tabular}{cccc}
\hline Perlakuan & \multicolumn{3}{c}{ Bobot tanaman segar melon $(\mathrm{g})$} \\
\hline & $\mathrm{M} 1$ & $\mathrm{M} 2$ & $\mathrm{M} 3$ \\
\hline \multirow{2}{*}{ V1 } & $500,00 \mathrm{~B}$ & $1066,67 \mathrm{~A}$ & $1083,33 \mathrm{~A}$ \\
& $\mathrm{a}$ & $\mathrm{a}$ & $\mathrm{a}$ \\
V2 & $550,00 \mathrm{C}$ & $883,33 \mathrm{~B}$ & $1250,00 \mathrm{~A}$ \\
& $\mathrm{a}$ & $\mathrm{ab}$ & $\mathrm{a}$ \\
V3 & $516,67 \mathrm{~B}$ & $700,00 \mathrm{~B}$ & $1316,67 \mathrm{~A}$ \\
& $\mathrm{a}$ & $\mathrm{bc}$ & $\mathrm{a}$ \\
V4 & $450,00 \mathrm{~B}$ & $516,67 \mathrm{~B}$ & $1333,33 \mathrm{~A}$ \\
& $\mathrm{a}$ & $\mathrm{C}$ & $\mathrm{a}$ \\
\hline
\end{tabular}

Keterangan: Nilai yang diikuti huruf kecil sama pada kolom dan huruf kapital sama pada baris menunjukkan tidak berpengaruh nyata menurut uji lanjut DMRT pada taraf $\alpha=5 \%$. 
Data pada Tabel 6. Menunjukan perlakuan volume air dan media tumbuh optimum pada bobot tanaman kering melon adalah V2M3 (1200 ml hari ${ }^{-1} \tan ^{-1}$ dengan media tumbuh tanah dan bokhasi) dengan nilai $95,80 \mathrm{~g}$.

Tabel 6. Rataan bobot tanaman kering melon pada perlakuan interaksi antara volume air dan media tumbuh

\begin{tabular}{cccc}
\hline \multirow{2}{*}{ Perlakuan } & \multicolumn{3}{c}{ Bobot tanaman kering melon $(\mathrm{g})$} \\
\cline { 2 - 4 } & $\mathrm{M} 1$ & $\mathrm{M} 2$ & $\mathrm{M} 3$ \\
\hline \multirow{2}{*}{ V1 } & $44,93 \mathrm{~B}$ & $77,47 \mathrm{~A}$ & $66,10 \mathrm{AB}$ \\
& $\mathrm{a}$ & $\mathrm{a}$ & $\mathrm{b}$ \\
V2 & $44,37 \mathrm{~B}$ & $50,23 \mathrm{~B}$ & $95,80 \mathrm{~A}$ \\
& $\mathrm{a}$ & $\mathrm{b}$ & $\mathrm{a}$ \\
V3 & $52,53 \mathrm{~B}$ & $52,43 \mathrm{~B}$ & $96,20 \mathrm{~A}$ \\
& $\mathrm{a}$ & $\mathrm{b}$ & $\mathrm{a}$ \\
V4 & $41,30 \mathrm{~B}$ & $36,53 \mathrm{~B}$ & $83,67 \mathrm{~A}$ \\
& $\mathrm{a}$ & $\mathrm{b}$ & $\mathrm{ab}$ \\
\hline
\end{tabular}

Keterangan: Nilai yang diikuti huruf kecil sama pada kolom dan huruf kapital sama pada baris menunjukkan tidak berpengaruh nyata menurut uji lanjut DMRT pada taraf $\alpha=5 \%$.

\section{Umur Bunga}

Pembungaan merupakan masa transisi dari fase vegetatif menuju fase generaif yang ditandai dengan munculnya kuncup-kuncup bunga. Data pada Tabel 4. Menunjukan perlakuan volume air irigasi tetes tidak berpengaruh nyata terhadap umur bunga melon. Hal ini diduga kondisi air cukup untuk melakukan transportasi dan metabolisme tanaman. Perlakuan media tumbuh berpengaruh sangat nyata terhadap umur bunga melon. Umur bunga melon paling cepat yaitu media tumbuh M3 (tanah dan bokhasi) dengan nilai rata-rata umur berbunga 19,28 HST dan terlama media tumbuh M1 (tanah dan arang sekam) dengan nilai rata-rata umur berbunga 26,98 HST. Dilihat pada data Tabel 1. dan 8. kandungan unsur hara fosfor media tumbuh dan jaringan daun $\mathrm{M} 3$ (tanah dan bokhasi) memiliki kandungan fospor lebih tinggi daripada media tumbuh M1 (tanah dan arang sekam) maupun M2 (tanah dan cocopeat). Ketersediaan unsur fospor sangat berperan pada pertumbuhan tanaman, fungsi dari fospor dalam tanaman adalah untuk merangsang pertumbuhan akar dan mempercepat pembungaan tanaman (Annisa \& Gustia, 2017). Menurut Sirenden et al. (2015) peran unsur fospor pada fase generatif adalah membantu proses pembentukan bunga, buah dan biji. Umur berbunga melon berkolerasi negatif dengan luas daun melon $(-0,735)$, lingkar buah (0,759 ), bobot tanaman segar $0,798)$ dan bobot buah melon $(-0,761)$ sehingga semakin luas daun melon, besarnya lingkar buah dan semakin berat bobot tanaman segar serta bobot buah melon maka akan diikuti cepatnya umur berbunga melon.

\section{Stomata}

Data pada Tabel 4. Menunjukan perlakuan volume air irigasi tetes dan media tumbuh tidak berpengaruh nyata terhadap bukaan stomata maupun kerapatan stomata. Hal ini diduga kondisi air pada setiap volume dan media tumbuh masih kondisi cukup atau tidak mengakibatkan titik 
layu permanen sehingga tidak tercekam air atau kekurangan air, Karena Menurut Sari et al. (2016) jika tanaman kekurangan air dapat menghambat laju fotosintesis, terutama pengaruhnya terhadap turgiditas sel penjaga stomata untuk membuka atau menutupnya stomata, Sedangkan Menurut Perkasa et al. (2017) jika transpirasi yang tinggi lebih banyak stomata yang menutup untuk menekan laju transpirasi yang terlalu tinggi dan menyebabkan tanaman cepat layu karena laju penyerapan air dengan transpirasi tidak seimbang. Menurut Irawan (2015) media tumbuh bahan organik (arang sekam, cocopiet dan bokhasi) mempunyai sifat remah sehingga udara, air, dan akar mudah masuk dalam fraksi tanah dan dapat mengikat air sehingga kondisi air cukup bagi tanaman melon.

\section{Klorofil}

Data pada Tabel 7. Menunjukan perlakuan volume air irigasi tetes berpengaruh sangat nyata terhadap kandungan klorofil a daun melon. Kandungan klorofil a daun melon terbesar perlakuan volume air V1 (600 ml hari $\left.{ }^{-1} \tan ^{-1}\right)$

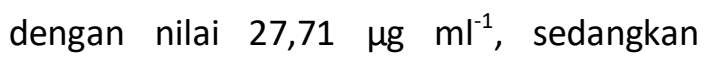
terkecil perlakuan volume air V4 $(2400 \mathrm{ml}$

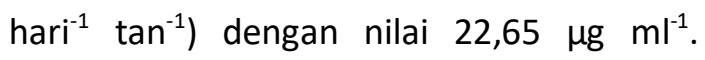
Perlakuan volume air irigasi tetes tidak berpengaruh nyata terhadap kandungan klorofil b maupun klorofil total daun melon. kandungan klorofil daun melon perlakuan media tumbuh tidak berpengaruh nyata baik terhadap kandungan klorofil $a$, klorofil $b$ maupun klorofil total.

Kandungan krorofil a perlakuan volume air V1 (600 $\mathrm{ml} \mathrm{hari}^{-1} \tan ^{-1}$ ) lebih tinggi, hal ini diduga disebabkan kondisi air masih cukup dan diduga lebih sedikitnya terjadi pencucian nitrogen oleh air pada media tumbuh karena polibag yang berlubang daripada perlakuan volume air V2 $(1200 \mathrm{ml}$ hari $\left.^{-1} \tan ^{-1}\right)$, V3 (1800 $\left.\mathrm{ml} \mathrm{hari}^{-1} \tan ^{-1}\right)$ maupun V4 (2400 ml hari $\left.{ }^{-1} \tan ^{-1}\right)$.

Tabel 7. Rataan kandungan klorofil a, klorofil $b$, klorofil total, $\mathrm{N}$ jaringan daun, $\mathrm{P}$ jaringan daun dan $\mathrm{K}$ jaringan daun pada perlakuan volume air dan media tumbuh

\begin{tabular}{ccccccc}
\hline Perlakuan & $\begin{array}{c}\text { Klorofil a } \\
\left(\mu \mathrm{g} \mathrm{ml}^{-1}\right)\end{array}$ & $\begin{array}{c}\text { Klorofil b } \\
\left(\mu \mathrm{g} \mathrm{ml}^{-1}\right)\end{array}$ & $\begin{array}{c}\text { Klorofil Total } \\
\left(\mu \mathrm{m} \mathrm{m}^{-1}\right)\end{array}$ & $\mathrm{N}(\%)$ & $\mathrm{P}(\%)$ & $\mathrm{K}(\%)$ \\
\hline V1 & $27,71 \mathrm{a}$ & $21,23 \mathrm{a}$ & $48,94 \mathrm{a}$ & $3,38 \mathrm{a}$ & $0,18 \mathrm{a}$ & $3,88 \mathrm{a}$ \\
V2 & $25,50 \mathrm{ab}$ & $17,45 \mathrm{a}$ & $\begin{array}{c}42,95 \mathrm{a} \\
2,29 \mathrm{~b}\end{array}$ & $0,17 \mathrm{a}$ & $3,50 \mathrm{a}$ \\
V3 & $24,83 \mathrm{ab}$ & $16,14 \mathrm{a}$ & $40,98 \mathrm{a}$ & $2,44 \mathrm{~b}$ & $0,17 \mathrm{a}$ & $3,31 \mathrm{a}$ \\
V4 & $22,65 \mathrm{~b}$ & $15,66 \mathrm{a}$ & $38,30 \mathrm{a}$ & $2,00 \mathrm{~b}$ & $0,15 \mathrm{a}$ & $3,05 \mathrm{a}$ \\
\hline KK (\%) & 8,72 & 36,80 & 16,67 & 14,80 & 17,70 & 14,08 \\
\hline M1 & $25,81 \mathrm{a}$ & $17,58 \mathrm{a}$ & $43,39 \mathrm{a}$ & $2,57 \mathrm{a}$ & $0,15 \mathrm{~b}$ & $3,71 \mathrm{a}$ \\
M2 & $24,20 \mathrm{a}$ & $15,37 \mathrm{a}$ & $39,57 \mathrm{a}$ & $2,38 \mathrm{a}$ & $0,13 \mathrm{~b}$ & $3,08 \mathrm{a}$ \\
M3 & $25,51 \mathrm{a}$ & $19,91 \mathrm{a}$ & $45,42 \mathrm{a}$ & $2,65 \mathrm{a}$ & $0,23 \mathrm{a}$ & $3,51 \mathrm{a}$ \\
\hline
\end{tabular}

Keterangan: Angka-angka yang diikuti oleh huruf kecil yang sama pada kolom yang sama tidak berpengaruh nyata menurut uji lanjut DMRT pada taraf $\alpha=5 \%$; KK $=$ Koefisien keragaman.

Menurut Khavid \& Bambang (2010) penyerapan nitrogen dalam jaringan daun tanaman akan dipergunakan sebagai bahan baku pembentukan klorofil. Secara umun kandungan klorofil a, klorofil b, dan klorofil total daun melon pada penelitian ini berwarna hijau dan bervariasi artinya tanaman melon tidak tercekam air, sesuai dengan pernyataan menurut Nio Song \& Banyo (2011) jika tanaman kekurangan air 
akan mempengaruhi semua aspek pertumbuhan tanaman, meliputi proses fisiologi, biokimia, anatomi dan morfologi. Kandungan klorofil a bekolerasi dengan kandungan klorofil total $(0,739)$, sehingga kenaikan kandungan klorofil a akan diikuti kenaikan kandungan klorofil total.

\section{Kandungan NPK Jaringan Tanaman Melon}

Analisis jaringan daun melon untuk mengetahui status hara NPK pada jaringan tanaman melon. Data pada Tabel 7. Menunjukan perlakuan volume air irigasi tetes bepengaruh sangat nyata terhadap kandungan nitrogen jaringan daun melon tetapi Perlakuan volume air irigasi tetes tidak berpengaruh nyata terhadap kandungan fosfor dan kalium jaringan daun melon. Perlakuan volume air V1 (600 ml hari $\left.{ }^{-1} \tan ^{-1}\right)$ memiliki kandungan rata-rata nitrogen terbesar yaitu 3,38\% daripada perlakuan volume air V2 (1200 $\left.\mathrm{ml} \mathrm{hari}^{-1} \tan ^{-1}\right), \mathrm{V} 3$ (1800 ml hari $\left.{ }^{-1} \tan ^{-1}\right)$ dan V4 (2400 ml hari ${ }^{-1}$ $\tan ^{-1}$ ) dengan masing - masing kandungan nitrogen yaitu 2,29, 2,26 dan 2,00\%. Hal ini diduga volume air V2, V3 dan V4 terjadi kehilangan atau pelindian nitrogen oleh air pada media tumbuh sehingga nitrogen yang terserap tanaman lebih sedikit daripada M3 disebabkan polibag berlubang dan sistem irigasi terpusat di daerah perakaran. Menurut Patti et al. (2013) berkurangnnya kandungan nitrogen pada media tumbuh karena dipengaruhi oleh tiga faktor yaitu pencucian bersama air draenase, penguapan dan diserap oleh tanaman.

Data pada Tabel 7. Perlakuan media tumbuh tidak berpengaruh nyata terhadap kandungan nitrogen dan kalium jaringan daun melon, tetapi berpengaruh sangat nyata terhadap kandungan fosfor jaringan daun melon, kandungan fosfor jaringan daun melon media tumbuh M3 (tanah dan bokhasi) memiliki kandungan terbesar dengan rata-rata yaitu $0,23 \%$ daripada kandungan fosfor jaringan daun melon pada media tumbuh M1 (tanah dan arang sekam) dan M2 (tanah dan cocopeat) dengan masing-masing 0,15 dan $0,13 \%$. Hal ini diduga karena kandungan hara fospor pada media tumbuh M3 (tanah dan bokhasi) lebih banyak daripada media tumbuh M1 (tanah dan arang sekam) dan M2 (tanah dan cocopeat) sehingga kandungan fosfor pada media tumbuh yang akan diserap oleh tanaman tersedia lebih banyak. Menurut Bachtiar et al. (2016) jenis media tumbuh mempengaruhi jumlah hara yang dapat diserap oleh tanaman.

\section{Buah Melon}

Data pada Tabel 8. Menunjukan perlakuan volume air irigasi tetes tidak berpengaruh nyata terhadap bobot buah melon, hal ini diduga kondisi air di setiap perlakuan volume air cukup untuk transportasi dan metabolisme tanaman. Perlakuan media tumbuh berpengaruh sangat nyata terhadap bobot buah melon. Bobot buah melon tertinggi media tumbuh M3 (tanah dan bokhasi) dengan rata-rata bobot buah $1,53 \mathrm{~kg}$, bobot buah melon terendah perlakuan media tumbuh M1 (tanah dan arang sekam) dengan rata-rata bobot buah 0,96 kg. Kandungan fosfor pada jaringan daun yang lebih tinggi pada media tumbuh tanah dan bokhasi (M3) akan merangsang pertumbuhan buah, sesuai menurut Annisa \& Gustia (2017) ketersediaan unsur fosfor dan kalium sangat diperlukan dalam proses pembentukan buah. Menurut Nelfi et al. (2020) Pemberian bokhasi dapat meningkatkan bobot buah dan lingkar buah tanaman melon. Hasil analisis korelasi bobot buah melon berkolerasi positif dengan bobot tanaman 
segar $(0,731)$, lingkar buah $(0,952)$ dan berkolerasi negatif dengan umur berbunga (0,761 ) sehingga kenaikan bobot tanaman segar, besarnya lingkar buah dan cepatnya umur berbunga maka akan diikuti kenaikan berat bobot buah melon.

Data pada Tabel 8. Menunjukan perlakuan volume air irigasi tetes maupun perlakuan media tumbuh tidak berpengaruh nyata terhadap brix atau rasa manis buah dan kadar air buah melon. Perlakuan volume air irigasi tetes tidak berpengaruh nyata terhadap Lingkar buah melon, sedangkan perlakuan media tumbuh berpengaruh sangat nyata. Perlakuan media tumbuh terhadap lingkar buah melon tertinggi yaitu media tumbuh M3 (tanah dan bokhasi) dengan nilai rata-rata lingkar buah $43,96 \mathrm{~cm}$ sedangkan terendah yaitu media tumbuh M1 (tanah dan arang sekam) dengan nilai rata-rata lingkar buah $38,14 \mathrm{~cm}$. Voume air irigasi tetes tidak meningkatkan lingkar buah diduga kondisi air cukup dan tidak mempengaruhi transportasi dan metabolisme tanaman disetiap volume air, sedangkan media tumbuh tanah dan bokhasi meningkatkan lingkar buah karena kondisi cukup air dan lebih tingginya unsur hara NPK pada media tumbuh dan jaringan daun (Tabel 1 dan 8) dapat meningkatkan laju fotosintesis dan diikuti peningkatan asimilat. Menurut Rahayu et al. (2011) selain faktor pemangkasan dan pengurangan buah saat tanaman melon masuk fase generatif asimilat lebih banyak di trasportasikan ke buah sehingga mempercepat pembesaran buah. Hasil analisis kolerasi lingkar buah melon berkolerasi positif dengan bobot buah $(0,952)$, bobot segar tanaman melon $(0,719)$ dan berkolerasi negatif dengan umur berbunga $(-0,759)$ sehingga kenaikan berat bobot buah, bobot segar tanaman dan cepatnya umur berbunga melon maka akan diikuti kenaikan besarnya lingkar buah melon.

Tabel 8. Rataan bobot buah melon, brix buah melon, lingkar buah melon, kadar air buah melon, prolin dan kandungan air nisbi daun (KAND) pada perlakuan volume air dan media tumbuh

\begin{tabular}{ccccccc}
\hline Perlakuan & $\begin{array}{c}\text { Bobot Buah } \\
\text { Melon (Kg) }\end{array}$ & $\begin{array}{c}\text { Brix Buah } \\
\text { Melon }\end{array}$ & $\begin{array}{c}\text { Lingkar Buah } \\
\text { Melon }(\mathrm{cm})\end{array}$ & $\begin{array}{c}\text { Kadar Air Buah } \\
\text { Melon (\%) }\end{array}$ & $\begin{array}{c}\text { Prolin }(\mu \mathrm{mol} \\
\left.\text { prolin } \mathrm{g}^{-1}\right)\end{array}$ & $\begin{array}{c}\text { KAND } \\
(\%)\end{array}$ \\
\hline V1 & $1,17 \mathrm{a}$ & $8,92 \mathrm{a}$ & $41,40 \mathrm{a}$ & $96,57 \mathrm{a}$ & $7,85 \mathrm{a}$ & $74,35 \mathrm{~b}$ \\
V2 & $1,30 \mathrm{a}$ & $8,81 \mathrm{a}$ & $42,19 \mathrm{a}$ & $96,62 \mathrm{a}$ & $5,50 \mathrm{a}$ & $74,17 \mathrm{~b}$ \\
V3 & $1,23 \mathrm{a}$ & $8,50 \mathrm{a}$ & $41,02 \mathrm{a}$ & $96,36 \mathrm{a}$ & $7,65 \mathrm{a}$ & $79,93 \mathrm{a}$ \\
V4 & $1,15 \mathrm{a}$ & $8,22 \mathrm{a}$ & $39,74 \mathrm{a}$ & $96,47 \mathrm{a}$ & $5,58 \mathrm{a}$ & $78,10 \mathrm{ab}$ \\
\hline KK (\%) & 14,54 & 9,89 & 5,01 & 0,49 & 37,26 & 3,02 \\
\hline M1 & $0,96 \mathrm{~b}$ & $8,15 \mathrm{a}$ & $38,14 \mathrm{~b}$ & $96,48 \mathrm{a}$ & $7,52 \mathrm{a}$ & $75,53 \mathrm{a}$ \\
M2 & $1,21 \mathrm{ab}$ & $8,75 \mathrm{a}$ & $41,17 \mathrm{ab}$ & $96,32 \mathrm{a}$ & $6,44 \mathrm{a}$ & $77,01 \mathrm{a}$ \\
M3 & $1,53 \mathrm{a}$ & $8,94 \mathrm{a}$ & $43,96 \mathrm{a}$ & $96,71 \mathrm{a}$ & $5,97 \mathrm{a}$ & $77,37 \mathrm{a}$ \\
\hline
\end{tabular}

Keterangan: Angka-angka yang diikuti oleh huruf kecil yang sama pada kolom yang sama tidak berpengaruh nyata menurut uji lanjut DMRT pada taraf $\alpha=5 \%$; KAND = Kadar air nisbi daun; KK = Koefisien keragaman.

\section{Kandungan Prolin}

Data pada Tabel 8. Menunjukan perlakuan volume air irigasi tetes dan media tumbuh tidak berpengaruh nyata terhadap kandungan prolin daun melon. Hasil analisis kolerasi kandungan prolin tidak berkolerasi terhadap bukaan stomata $(-0,091)$ dan KAND $(-0,139)$. Hal ini diduga karena dinamika 
lengas yang terjadi tidak mengakibatkan tanaman kekurangan air/kekeringan atau cukup air sehingga pemberian air tiap perlakuan tidak meningkatkan kadar prolin. Menurut Borgo et al. (2015) jika tanaman melon kekurangan air maka prolin terakumulasi dalam banyak tanaman sebagai respons terhadap tekanan abiotik (kekeringan/kekurangan air).

\section{KAND (Kandungan Air Nisbi Daun)}

Data pada Tabel 8. Menunjukan perlakuan volume air irigasi tetes berpengaruh nyata terhadap kandungan air nisbi daun melon. Kandungan air nisbi daun melon tertinggi yaitu volume air V3 dan V4 dengan nilai rata-rata 79,93 dan $78,10 \%$, sedangkan kandungan air nisbi daun melon terkecil yaitu volume air V1 dan V2 dengan nilai rata-rata 74,35 dan $74,17 \%$. Menurut Setiawan et al. (2013) penurunan nilai kandungan air nisbi daun melon berkorelasi negatif dengan jumlah volume penyiraman, semakin lama atau sedikitnya tanaman mendapatkan pasokan air semakin rendah nilai kandungan air nisbi daun tanaman melon tersebut.

Data pada Tabel 8. Menunjukan perlakuan media tumbuh tidak berpengaruh nyata terhadap kandungan air nisbi daun melon, Hal ini diduga dinamika lengas yang terjadi tidak mempengaruhi kandungan air nisbi daun melon atau cukup dan tidak mempengaruhi transportasi di setiap media tumbuh, karena penambahan media tumbuh bahan organik (arang sekam, cocopeat, dan bokhasi) mempunyai kemampuan menyediakan kapasitas tukar kation, kapasitas memegang air, mampu menyediakan unsur hara makro dan mikro, aerasi dan darinase baik, serta menyediakan oksigen (Bariyyah et al., 2015).

\section{SIMPULAN}

1. Volume air dengan irigasi tetes $600 \mathrm{ml}$ hari ${ }^{-1} \tan ^{-1}, 1200 \mathrm{ml}$ hari ${ }^{-1} \tan ^{-1}, 1800 \mathrm{ml}$ hari ${ }^{-1} \tan ^{-1}$ dan $2400 \mathrm{ml}$ hari $^{-1} \tan ^{-1}$ memiliki pengaruh yang sama terhadap pertumbuhan dan hasil, namun volume air dengan irigasi tetes $600 \mathrm{ml} \mathrm{hari}^{-1} \tan ^{-1}$ memiliki kandungan klorofil a dan $\mathrm{N}$ jaringan daun tertinggi dengan masingmasing $27,71 \mu \mathrm{g} \mathrm{ml}^{-1}$ dan 3,38\%.

2. Media tumbuh kombinasi tanah dan bokhasi mampu meningkatkan pertumbuhan dan hasil; luas daun $\left(347.09 \mathrm{~cm}^{2}\right)$, total Panjang akar $(1853.83$ $\mathrm{cm})$, bobot tanaman segar (1245.83 g), bobot tanaman kering ( $85.44 \mathrm{~g})$, umur berbunga (19.28 HST), bobot buah (1.53 $\mathrm{Kg})$ dan lingkar buah $(43.96 \mathrm{~cm})$.

3. Volume air $600 \mathrm{ml} \mathrm{hari}^{-1} \tan ^{-1}, 1200 \mathrm{ml}$ hari ${ }^{-1} \tan ^{-1}, 1800 \mathrm{ml} \mathrm{hari}^{-1} \tan ^{-1}$ dan 2400 $\mathrm{ml}$ hari ${ }^{-1} \tan ^{-1}$ dengan irigasi tetes pada media tumbuh tanah dan bokhasi terhadap pertumbuhan dan hasil dapat meningkatkan bobot tanaman segar dan bobot tanaman kering melon.

4. Volume air $600 \mathrm{ml}$ hari ${ }^{-1} \tan ^{-1}$ optimum dengan media tumbuh tanah dan bokhasi pada pertumbuhan dan hasil bobot tanaman segar melon (1083,33 g) sedangkan pada bobot tanaman kering melon (95,80 g) adalah volume air 1200 $\mathrm{ml}$ hari $^{-1} \tan ^{-1}$ dengan media tumbuh tanah dan bokhasi.

\section{UCAPAN TERIMAKASIH}

Ucapan terimakasih disampaikan kepada PT. East West Seed Indonesia yang telah memberikan kesempatan penelitian.

\section{DAFTAR PUSTAKA}

Annisa, P., \& Gustia, H. (2017). Respon Pertumbuhan dan Produksi Tanaman 
Melon Terhadap Pemberian Pupuk Organik Cair Tithonia diversifolia. Prosiding Seminar Nasional 2017 Fakultas Pertanian UMJ, 104-114.

Ashari, A., Nurcahyani, E., Qudus, H. I., \& Zulkifli, Z. (2018). Analisis Kandungan Prolin Planlet Jeruk Keprok Batu 55 (Citrus Reticulata Blanco Var. Crenatifolia) Setelah Diinduksi Larutan Atonik dalam Kondisi Cekaman Kekeringan Secara in Vitro. Analit: Analytical and Environmental Chemistry, 3(01), 69-78. https://doi.org/10.23960/aec.v3.i1.201 8.p69-78

Bachtiar, B., Ghulamahdi, M., Melati, M., Guntoro, D., \& Sutandi, A. (2016). Kecukupan Hara Fosfor pada Pertumbuhan dan Produksi Kedelai Dengan Budidaya Jenuh Air di Tanah Mineral dan Bergambut. Jurnal IImu Tanah dan Lingkungan, 18(1), 21. https://doi.org/10.29244/jitl.18.1.2127

Bariyyah, K., Suparjono, S., \& Usmadi, U. (2015). Pengaruh Kombinasi Komposisi Media Organik dan Konsentrasi Nutrisi terhadap Daya Hasil Tanaman Melon (Cucumis melo L.). PLANTA TROPIKA: Jurnal

https://borang.umy.ac.id/index.php/pt /article/view/2533

Budi, S., \& Sigit, D. (2017). Keanekaragaman dan potensi sumber daya genetik melon. Yogyakarta: Gajah Mada Universty Press.

Borgo, L., Marur, C. J., \& Vieira, L. G. E. (2015). Efeitos do alto acúmulo de prolina na ultraestrutura de cloroplastos e mitocôndrias e no ajustamento osmótico de plantas de tabaco. Acta Scientiarum - Agronomy, $37(2)$, 191-199. https://doi.org/10.4025/actasciagron.v 37i2.19097

Darmawan, A. F., Herlina, N., \& Soelistyono,
R. (2013). Pengaruh Berbagai Macam Bahan Organik dan Pemberian Air Terhadap Pertumbuhan dan Hasil Tanaman Sawi ( Brassica Juncea L.) The Effect of Various Kinds of Organic Matter and Watering on Growth and Yield of Mustard ( Brassica Juncea L .). 1(5), 389-397.

Dede Haryadi, Husna Yetti, S. Y. (2015). Pengaruh Pemberian Beberapa Jenis Pupuk Terhadap Pertumbuhan dan Produksi Tanaman Kailan (Brassica Alboglabra L.). The Journal of the Japan Prosthodontic Society, 15(2), 472-473.

Diding Suhandy, Ahmad Tusi, I. N. dan M. Y. (2015). Analisis Hubungan Tingkat Pemberian Air Irigasi Terhadap Nilai Leaf Water Potential dan Kandungan Padatan. July 2017. https://www.researchgate.net/profile/ Ahmad_Tusi/publication/318700475_A nalisis_Hubungan_Tingkat_Pemberian_ Air_Irigasi_terhadap_Nilai_Leaf_Water _Potential_dan_Kandungan_Padatan_T erlarut_pada_Tanaman_Melon/links/5 97825770f7e9b277721d885/AnalisisHubungan- $\mathrm{Ti}$

Irawan, A. (2015). Pemanfaatan cocopeat dan arang sekam padi sebagai media tanam bibit cempaka wasian (Elmerrilia ovalis). 1 , 805-808. https://doi.org/10.13057/psnmbi/m01 0423

Khavid Faozi dan Bambang Rudianto Wijonarko. (2010). Serapan Nitrogen dan Beberapa Sifat Fisiologi Tanaman Padi Sawah dari Berbagai Umur Pemindahan Bibit. 10, 93-101.

Kurniastuti, T., \& Faustina, D. R. (2019). Pengaruh Dosis Pupuk Kompos Jerami dan Jenis Mulsa Terhadap Pertumbuhan dan Produksi Tanaman Melon (Cucumis melo L.). Jurnal Pertanian Terpadu. http://ojs.stiperkutim.ac.id/index.php/j pt/article/view/trikurniastuti 
Laksono, R. A. (2018). Pengujian Efektivitas Tipe Pemangkasan Terhadap Produksi Tiga Varietas Semangka pada Hidroponik Sistem Fertigasi (Drip Irrigation). Paspalum: Jurnal Ilmiah Pertanian, 6(2), 103. https://doi.org/10.35138/paspalum.v6i 2.93

Manh, V. H., \& Wang, C. H. (2014). Vermicompost as an Important Component in Substrate: Effects on Seedling Quality and Growth of Muskmelon (Cucumis Melo L.). APCBEE Procedia, 8(Caas 2013), 32-40. https://doi.org/10.1016/j.apcbee.2014. 01.076

Mawardi, M. (2016). Irigasi asas dan praktek. Yogyakarta: Bursa Ilmu.

Monteiro, R. O. C., Coelho, R. D., \& Monteiro, P. F. C. (2014). Produtividade da água e de nutrientes em melão fertirrigado por gotejamento subterrâneo sob mulching em diferentes tipos de solo. Ciencia Rural, 44(1),25-30. https://doi.org/10.1590/S010384782013005000151

Muhadan Syah, Husna Yetti, dan S. Y. (2016). Pengaruh Pemberian Bokashi dan Npk Terhadap Pertumbuhan dan Produksi Tanaman Semangka (Citrullus vulgaris Schard). 4(2), 25-28.

Muttaqin, M., \& Amalia, N. S. (2019). Pertumbuhan, Produksi, dan Kualitas Buah Melon dengan Pemberian Pupuk Pertumbuhan, Produksi , dan Kualitas Buah Melon dengan Pemberian Pupuk Silika (Growth, Yield, and Fruit of Melon Quality Using Silica Fertilizer ). October. https://doi.org/10.18343/jipi.24.4.366

Nelfi t. unga, Anshar, M., \& Laode, S. (2020). Pengaplikasian Dosis Pupuk Bokashi dan $\mathrm{KNO}_{3}$ Terhadap Pertumbuhan Dan Hasil Tanaman Melon (Cucumis melo L.). E-j Agrotekbis, 8(1), 38-45.
Nio Song, A., \& Banyo, Y. (2011). Konsentrasi Klorofil Daun Sebagai Indikator Kekurangan Air pada Tanaman. Jurnal Ilmiah Sains, 15(1), 166. https://doi.org/10.35799/jis.11.2.2011. 202

Patti, P. S., Kaya, E., \& Silahooy, C. (2013). Analisis Status Nitrogen Tanah dalam Kaitannya dengan Serapan. Agrologia, 2(1), 78-79.

Perkasa, A. Y., Siswanto, T., Shintarika, F., \& Sji, T. G. (2017). Pertanian Presisi. Jurnal Pertanian Presisi, 01(01), 59-72.

Pratama, A. J., \& Laily, A. N. (2015). Analisis Kandungan Klorofil Gandasuli (Hedychium gardnerianum Shephard ex Ker-Gawl) pada Tiga Daerah Perkembangan Daun yang Berbeda. Seminar Nasional Konservasi Dan Pemanfaatan Sumber Daya Alam, 216219.

http://jurnal.fkip.uns.ac.id/index.php/k psda/article/view/5377

Rahayu, A., Serhalawan, R., \& Munandar, E. (2011). Produksi dan Kualitas Buah Melon ( Cucumis melo L .) pada Jumlah Buah Per Tanaman yang Berbeda. Jurnal Pertanian, 2(2), 139-144. https://ojs.unida.ac.id/jp/article/downl oad/579/pdf

Rasilatu, F., Musa, N., \& Pembengo, W. (2016). Respon Produksi Dua Varietas Tanaman Melon (Cucumis melo. L) Terhadap Waktu Pemangkasan Pucuk. Skripsi, 5(3), 321-326. https://repository.ung.ac.id/get/karyail miah/4726/Respon-Produksi-DuaVarietas-Tanaman-Melon-Cucumismelo-L-Terhadap-WaktuPemangkasan-Pucuk.pdf

Rosadi. B. 2015. Dasar-dasar teknik irigsi. Graha IImu, Cetakan pertama. Yogyakarta.

Rosawanti, P. (2016). Pertumbuhan Akar Kedelai pada Cekaman Kekeringan ( The 
Growth of Soybean Root on Drought Stress ) Pienyani Rosawanti. 3(1), 2128.

Sari, R. M. P., Maghfoer, M. D., \& Koesriharti. (2016). Terhadap Pertumbuhan dan Hasil the Influence of Watering Frequency and Dose Chicken Manure on Growth and Yield of Pakchoy (Brassica rapa L . var . chinensis ). Jurnal Produksi Tanaman, 4(5), 342-351.

Setiawan, S., Tohari, T., \& Shiddieq, D. (2013). Pengaruh Cekaman Kurang Air Terhadap Beberapa Karakter Fisiologis Tanaman Nilam (Pogostemon cablin Benth). Jurnal Penelitian Tanaman Industri, 19(3), 108. https://doi.org/10.21082/jlittri.v19n3.2 013.108-116

Sirenden, R. T., Suparno, S., \& Winerungan, S. A. J. (2015). Hasil Tanaman Melon (Cucumis Melo, L) Setelah Pemupukan Posfor dan Gandasil B Pada Tanah Gambut Pedalaman. AgriPeat. http://ejournal.upr.ac.id/index.php/Agp/article /view/1179

Sulistyono, E., \& Riyanti, H. (2016). Volume Irigasi untuk Budidaya Hidroponik Melon dan Pengaruhnya terhadap Pertumbuhan dan Produksi. Jurnal Agronomi Indonesia (Indonesian Journal of Agronomy), 43(3), 213. https://doi.org/10.24831/jai.v43i3.112

47

Susilo, D. E. H. (2015). Identifikasi Nilai Konstanta Bentuk Daun untuk Pengukuran Luas Daun Metode Panjang Kali Lebar pada Tanaman Hortikultura di Tanah Gambut. Anterior Jurnal, 14(2), 139-146.

https://doi.org/10.33084/anterior.v14i 2.178

Wahyuningsih, W., Proklamasiningsih, E., \& Dwiati, M. (2017). Serapan Fosfor dan Pertumbuhan Kedelai (Glycine max) pada Tanah Ultisol dengan Pemberian Asam Humat. Biosfera, 33(2), 66. https://doi.org/10.20884/1.mib.2016.3 3.2.345 